\title{
LIFE IN A SHRINKING WORLD: THERMAL PHYSIOLOGY AND ACTIVITY OF DIURNAL ALPINE MAMMALS IN RELATION TO CLIMATE CHANGE
}

\author{
JAMES A. WILSON \\ UNIVERSITY OF NEBRASKA $\uparrow$ OMAHA
}

\begin{abstract}
$\uparrow \quad$ ABSTRACT
The effects of increased global temperatures are being measured in many biological systems. Given the complexity of biological systems, their responses to a changing climate are difficult to predict. Physiologic processes are particularly susceptible to temperature, leading to a species specific optimal range of habitable temperatures. As global temperatures increase, species will be exposed to a changing range of potentially stressful temperatures, especially in species currently living at their thermal limits (e.g., alpine mammals). Warming temperatures may force alpine species to move to higher elevations to maintain thermoneutrality. Ultimately, if temperatures increase as predicted, alpine mammals may be unable to move higher and may face localized extinctions.
\end{abstract}

I hypothesize that, many alpine mammals are currently living at the upper range of their thermoneutral zone and, in response to warming temperatures; alpine mammals will experience ambient temperatures above their upper critical temperature which will limit their activity period. I will measure the metabolic thermoneutral zone of small mammals in relation to temperature at four montane sites in the western U.S. We will focus on small diurnal mammals (chipmunks and pikas) as they are prolific and susceptible to high temperatures. The proposed study will not only provide sorely needed information on the basic thermal requirements of numerous alpine small mammals in the U.S., but that information can be used to generate physiologically relevant models to predict future changes in the altitudinal ranges of these species.

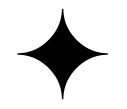

\section{$\uparrow \quad$ INTRODUCTION}

The Earth has experienced substantial warming over the last century, with anthropogenic sources as the likely cause (Houghton et al., 2001). Within North America, mean atmospheric temperature has warmed by $0.7^{\circ} \mathrm{C}$ during the past century, leading to heterogeneous changes in precipitation across the continent. Houghton et al. (2001) predicted that individual physiographic regions of the USA will show unique alterations in response to warming trends. For example, the Sierra Nevada is predicted to have increased winter rainfall, less snowfall, more summer drying, and increased temperatures. In contrast, the Rocky Mountains will show an altitudinal increase in the winter-spring snowline, increased snowfall combined with earlier snowmelt, and increased summer temperatures and drying. Alterations in large-scale climate patterns are predicted to have important effects on species inhabiting these montane regions of the western United States. Many of these predictions are already being observed by scientists, including changes in phenology (Post and Stenseth 1999), species distributions (Payette 1987, Floyd 2004, Gian-Reto et al. 2005), body size (Smith, Browning \& Shepherd, 1998; Fernández-Salvador et al. 2005), reproductive output (Lewis 1993), hibernation patterns (Inouye et al. 2000, Blumstein et al. 2004), and community structure (Brown et al. 1997).

Biological systems are complex making it difficult to predict responses to climate change. As a result, McCarthy et al. (2001) state "there is a strong need for a long-term comprehensive system to monitor forest health and disturbance regimes over regional scales that can function as an early warning 
system for climate change effects on forests." In addition, McCarthy et al. (2001) warns that climate change can lead to loss of specific ecosystem types, such as high alpine areas. Complicating matters, it is not known whether species have the ability to adapt to rapidly changing environments through normal evolutionary processes (Berteaux et al. 2004, Humphries et al. 2004).

Monitoring the health of species requires an understanding of their basic requirements, many of which are based in their physiologic needs. At the basest level, living beings are constrained by their ability to tolerate various physical conditions (McNab 2002). Species have a range of ambient temperatures they can comfortably endure. Outside this range, individuals experience stress and eventually death. As global temperatures increase, species will be exposed to a warmer range of temperatures, some of which may place sensitive species in a thermally stressful environment.

Alpine species are rarely, if ever, exposed to high temperatures and will likely show the greatest response to warming. Their only options may be to move to higher, colder areas on the mountain or perish. Ultimately, if temperatures increase as predicted, alpine adapted mammals may be unable to move higher and may face localized extinctions. Unfortunately, national parks across the United States are reporting that mammalian species are already moving to higher altitudes. For example, in Yosemite National Park, the American pika, Ochotona princeps once found at Olmstead Point (elevation 2,500 m), no longer occurs at these lower elevations, and may be facing extinction pressure, as has been observed on other western mountains (Beever et al. 2003).

\section{$\uparrow \quad$ METHODS}

\section{Capture of Animals}

Animals will be captured using standard traplines of Tomahawk (model 201) traps baited with rolled oats and black oil sunflower seeds mixed with peanut butter (Yellow-pine chipmunks Neotamias amoenus and Least chipmunks $N$. minums) or locally collected vegetation (Amerincan pikas). Traps will be set in the early morning (just after sunrise) and checked every 2 hours. All traps will be closed from 12:00-16:00 hrs to prevent thermal stress to captured animals. Captured animals will be weighed, sexed, assessed for reproductive condition, and have numbered eartags applied to each ear. Due to their fragility, pikas require modified trap methods, which are discussed below. All fieldwork will be conducted under the auspices of an approved animal care and use protocol and meet guidelines recommended by the American Society of Mammalogists (Gannon and Forbes 2007).

Pikas are easily stressed, especially during warm or cold weather $\left(>70^{\circ} \mathrm{F}\right.$ or $\left.\angle 45^{\circ} \mathrm{F}\right)$ and will be trapped using open mesh traps to prevent overheating. Traps will be set in the talus on a stable rock and covered on all sides, back, and top with additional rocks that will protect the animal from sun, precipitation, and predators. Traps will be opened early in the morning and checked every 2 - $4 \mathrm{hrs}$, depending on weather conditions.

Traps containing pikas will be placed into a cloth bag for immediate transport to the on-site metabolic chamber. Pikas will be transferred to an anesthesia jar, which consists of a see-through plastic jar with airholes perforating the bottom to prevent the build-up of carbon dioxide. A small perforated container (film canister) containing cotton soaked with a liquid anesthesia (isoflurane) will be placed in the larger anesthesia chamber with the pika. Following anesthetization pikas will be removed from the chamber, weighted, sexed, given eartags, and placed into the metabolic chamber.

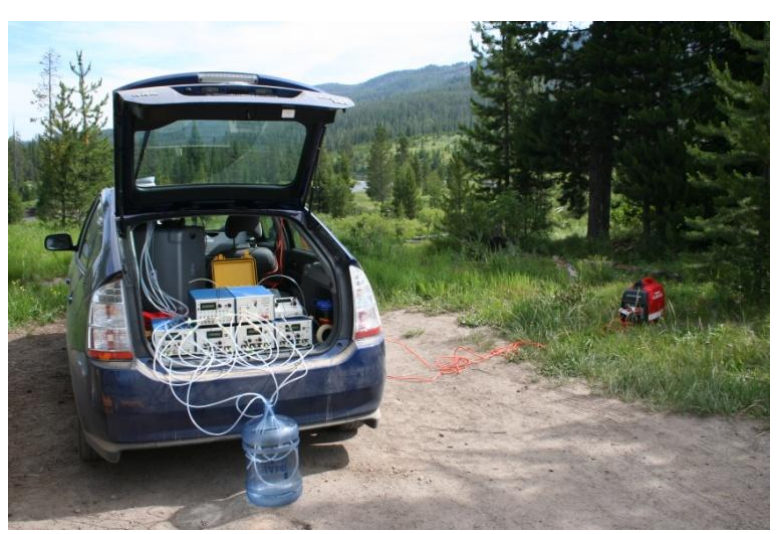

Figure 1. Field setup of the portable metabolic chamber. The metabolic chamber is powered through a portable generator (right) and all metabolic equipment is contained within the vehicle.

\section{Metabolic Response Curves}

Trials to measure metabolic parameters (thermal-neutral zone; upper/lower critical temperature) will be performed in the field using a Sable Systems Inc. metabolic chamber (Hayes and O'Connor 1999, Campbell and Hochachka 2000, Terblanche et al. 2006). The Sable Systems 


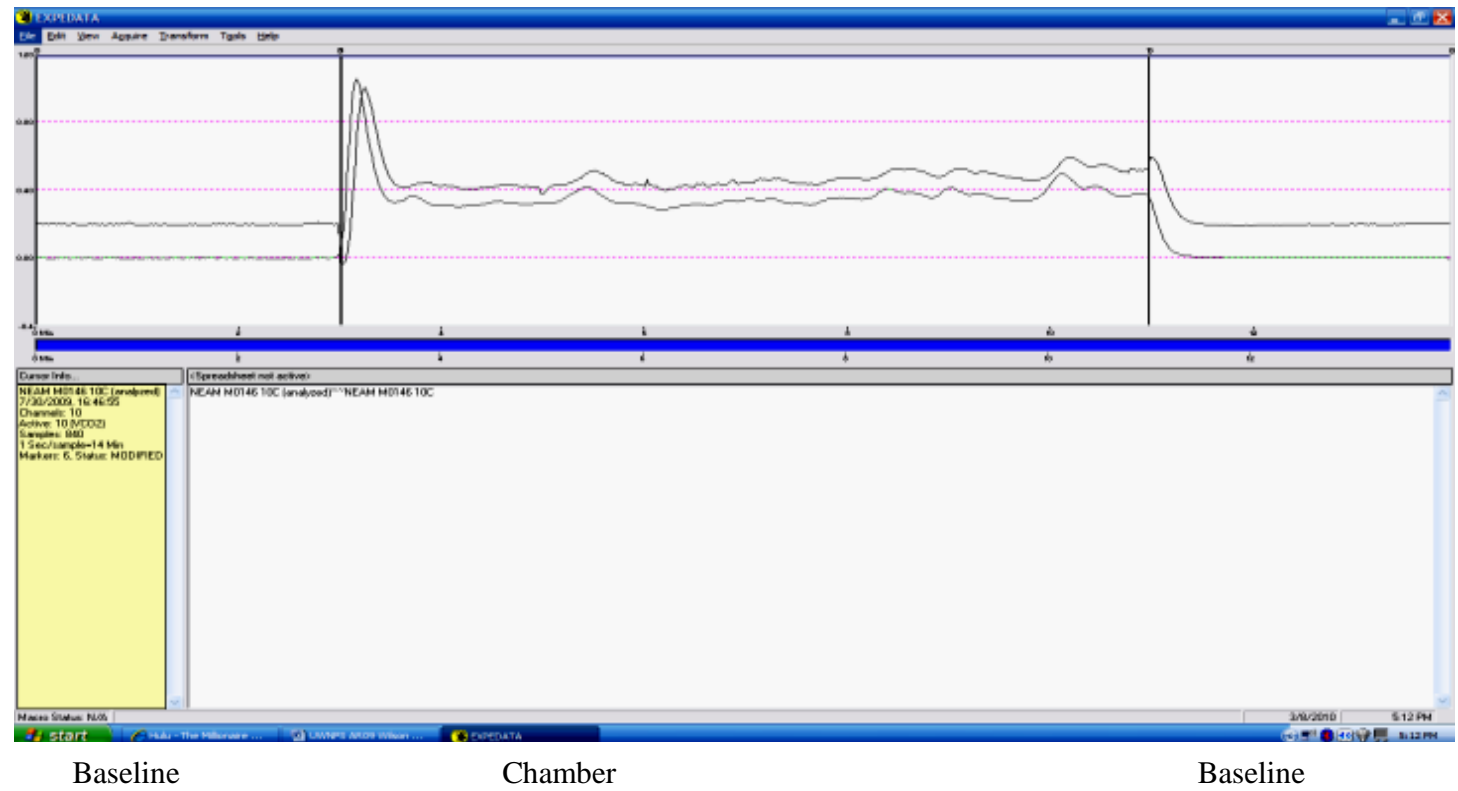

Figure 2. Example of a metabolic response curve following analysis using the Expedata analysis program. The graph shows $\mathrm{VO}_{2}$ (top graph) and $\mathrm{VCO}_{2}$ (bottom graph) of a single animal (Yellow-pine Chipmunk) at a single temperature $\left(10^{\circ} \mathrm{C}\right)$. Baseline data obtained from ambient airflow is shown to the left and right of the vertical lines (labeled baseline above) and airflow from the animal subject is shown in the center (labeled chamber). Metabolic rates are calculated as the average $\mathrm{VO}_{2}$ and $\mathrm{VCO}_{2}$ addition across the entire chamber.

Metabolic Chamber is highly mobile and will be brought to the site of capture, powered by a portable generator (Figure 1). Individuals will have their metabolic rates measured in situ which will reduce problems associated with capture, transport, and housing stress which may influence metabolic rates.

Metabolic rates (Figure 2.) will be measured using a flow through respirometry system (Sable Systems, Inc., Las Vegas, NV). Individual animals will be placed into individual respirometry chamber (950 ml volume) and attached to airflow lines. Individual respirometry chambers will be placed into a controllable environmental chamber. To prevent dehydration and allow individuals access to food resources, an apple slice will be provided to individuals inside the respirometry chamber. Apple slices will not affect metabolic measurements and during preliminary metabolic trials the addition of apple slices for water reduced problems with dehydration. Individuals will be subjected to a series of metabolic trials at increasing/decreasing temperatures. At each temperature that the environmental chamber is set, each individual animal will be subjected to a metabolic trial. Each metabolic trial will consist of a $5 \mathrm{~min}$ baseline of ambient air, followed by a $15 \mathrm{~min}$ sample of the animal's respirometry chamber, followed again by a 5 min baseline. After all four individuals have run a metabolic trial the temperature in the environmental chamber will be adjusted to the next experimental temperature and animals will be allowed to acclimate to the new temperature for $45 \mathrm{~min}$. Experimental environmental temperatures will range from $10^{\circ} \mathrm{C}$ to $40^{\circ} \mathrm{C}$ and will be adjusted in 3 or $5^{\circ} \mathrm{C}$ increments. Due to their lower heat tolerance, pikas will not be subjected to high temperatures $\left(>28^{\circ} \mathrm{C}\right)$. Following metabolic trials, all animals will be returned to the point of capture and released.

Airflow to the respirometry chambers will be pumped at a rate of $500 \mathrm{ml} / \mathrm{min}$ and $300 \mathrm{ml} / \mathrm{min}$ for pikas and chipmunks respectively using individual Mass Flow Systems (Sable Systems, Las Vegas, NV) that standardize and monitor flow rates. After exiting the respirometry chambers, air will be directed through a computer controlled Baselining Unit and Multiplexor (Sable Systems, Las Vegas, $\mathrm{NV}$ ) that will allow individual respirometry chambers or ambient air to enter the analyzer and be recorded by a laptop computer. Air being analyzed will flow into a Relative Humidity Meter (RH-300, Sable Systems, Las Vegas, NV) and then into the $\mathrm{O}_{2}, \mathrm{CO}_{2}$, and barometric pressure analyzer (Foxbox, Sable Systems, Las Vegas, NV). All data (airflow rate, ambient barometric pressure, chamber relative humidity, oxygen and carbon dioxide concentration, and environmental chamber temperature) will be 
recorded to a computer file using the UI-2 Controller (Sable Systems, Las Vegas, NV).

Table 1. Potential study species of diurnal sciurids and the American pika found in alpine habitats of the western United States.

\begin{tabular}{|c|c|c|c|c|}
\hline \multirow[b]{2}{*}{ Species } & \multicolumn{2}{|c|}{$\begin{array}{c}\text { Sierra } \\
\text { Nevada/Cascade } \\
\end{array}$} & \multicolumn{2}{|c|}{ Rocky Mountains } \\
\hline & $\begin{array}{c}\text { Yosemite } \\
\text { NP }\end{array}$ & $\begin{array}{l}\text { Lassen } \\
\text { NP }\end{array}$ & $\begin{array}{c}\text { Rocky } \\
\text { Mtn Bio. } \\
\text { Lab }\end{array}$ & $\begin{array}{c}\text { Grand } \\
\text { Teton } \\
\text { NP }\end{array}$ \\
\hline $\begin{array}{l}\text { Golden-mantled } \\
\text { Ground Squirrel } \\
\text { (Spermophilus } \\
\text { lateralis) }\end{array}$ & $X$ & $X$ & $X$ & $X$ \\
\hline $\begin{array}{l}\text { Belding's Ground } \\
\text { Squirrel (Spermophilus } \\
\text { beldingi) }\end{array}$ & $X$ & X & & \\
\hline $\begin{array}{l}\text { Thirteen Lined Ground } \\
\text { Squirrel (Spermophilus } \\
\text { Tridecemlineatus) }\end{array}$ & & & $X$ & \\
\hline $\begin{array}{l}\text { Lodgepole Chipmunk } \\
\text { (Neotamias speciosus) }\end{array}$ & $X$ & $\mathrm{X}$ & & \\
\hline $\begin{array}{l}\text { Alpine Chipmunk } \\
\text { (Neotamias alpinus) }\end{array}$ & $\mathrm{X}$ & $\mathrm{X}$ & & \\
\hline $\begin{array}{l}\text { Yellow Pine } \\
\text { Chipmunk (Neotamias } \\
\text { amoenus) }\end{array}$ & $X$ & X & $X$ & $X$ \\
\hline $\begin{array}{l}\text { Least Chipmunk } \\
\text { (Neotamias minimus) } \\
\text { Uinta Chipmunk }\end{array}$ & & & $X$ & $\mathrm{X}$ \\
\hline $\begin{array}{l}\text { (Neotamias umbrinus) } \\
\text { Allen's Chipmunk } \\
\text { (Neotamias senex) } \\
\text { Long-eared Chipmunk } \\
\text { (Neotamias }\end{array}$ & $\mathrm{X}$ & $\mathrm{X}$ & $\mathrm{X}$ & $\mathrm{X}$ \\
\hline $\begin{array}{l}\text { quadrimaculatus) } \\
\text { Colorado Chipmunk } \\
\text { (Neotamias }\end{array}$ & $\mathrm{X}$ & $\mathrm{X}$ & & \\
\hline $\begin{array}{l}\text { quadrivittatus) } \\
\text { American Pika } \\
\text { (Ochotona princes) }\end{array}$ & X & $X$ & $\mathrm{X}$ & $X$ \\
\hline
\end{tabular}

Data files will be analyzed using EXPEDATA (Sable Systems, Las Vegas, NV) for each recording, baseline concentrations of $\mathrm{O}_{2}$ and $\mathrm{CO}_{2}$ obtained from ambient airflow will be used to calculate percent use of $\mathrm{O}_{2}$ and percent addition of $\mathrm{CO}_{2}$ by the animal. Rates of $\mathrm{O}_{2}$ depletion and $\mathrm{CO}_{2}$ addition $(\mathrm{ml} / \mathrm{hr})$ will be calculated as the product of flow rate and percent depletion/addition. Rates of $\mathrm{O}_{2}$ depletion and $\mathrm{CO}_{2}$ addition will be averaged across the entire $15 \mathrm{~min}$ sample from the respiration chamber resulting in a single metabolic response value $(\mathrm{ml} / \mathrm{hr})$ at the given environmental temperature.

Therefore, each individual chipmunk and pika will have a series of metabolic rates at given environmental temperatures. These temperature- metabolic rate values will then be plotted to give the metabolic response curve. The upper critical temperature of these metabolic response curves will be calculated using a breakpoint analysis (Robbins 1986, Nickerson et al. 1989) that will identify the point at which metabolic rates increase in response to warming temperatures.

\section{RESULTS}

During the summer of 2009, preliminary work was done in two Rocky Mountain sites: Grand Teton National Park (GTNP), Wyoming and Rocky Mountain Biological Lab (RMBL), Colorado. The purpose of the preliminary season was to show that the proposed methodology would be viable, not harm the animals, and provide cost-effective data and research experience for students. In the summer of 2009, I took one student to GTNP and RMBL to perform the preliminary study. We captured and ran metabolic trials on 12 pikas, 10 Least chipmunks, and 3 Yellowpine chipmunks. During the preliminary study, data was successfully obtained, no animals were harmed, and all animals were released following metabolic trials. I feel confident that the proposed methodology will work and provide the necessary information for this study.

I collected data during the preliminary study and I am currently working on analyzing these data. For each animal at each temperature a data file is generated (Figure 2) resulting in a series of data files for each individual analyzed. These files require a number of steps to transform the raw data file into standardized $\mathrm{VO}_{2}$ and $\mathrm{VCO}_{2}$ traces (Figure 2). A mean $\mathrm{VO}_{2}$ and $\mathrm{VCO}_{2}$ will be calculated across the 15-min trial period and used to generate the metabolic response curves.

\section{DISCUSSION}

\section{Metabolic Response Curves}

I am currently analyzing the data files obtained during metabolic trials during the summer of 2009. A problem with the relative humidity sensor was discovered after the summer session. The humidity sensor was not calibrated properly and was overestimating water vapor in the chambers and throwing off the results. The humidity sensor was calibrated properly and a correction factor was calculated and applied to the summer data. 
In addition, I traveled to the Sable Systems Company (Las Vegas) and received additional training on analyzing summer data. Because of the field nature of data collection, special procedures are required to analyze the data. Specifically, drift in all of the gas analyses occurs as a result of changes in the ambient temperature associated with the warming of the day. However, I now know how to deal with such drifting problems.

The major goal of the summer 2009 data collection was to try our methods in real field situations and identify potential problems. I have accomplished this goal and have determined that data was obtained easily and is viable for the intended study. In addition, we have identified additional data that can be recorded to help with climate models. Specifically, I intend to add a behavioral component. I intend to measure daily ambient temperature cycles in various microclimates (open sunshine, shaded forest, under rocks, etc) and associate them with the activity of individuals.

During the summer of 2010 I hope to complete the measurement of metabolic rates for all species of interest (Table 1). In addition, I intend to observe focal animals of each species and measure the daily behavior and activity while simultaneously measuring daily temperature changes using small Thermochron iButtons placed in various microclimates. I will record when an individual becomes active, what behaviors it performs, and what microclimate it occupies.

During the summer of 2010, we hope to provide an opportunity for a graduate student and 2 undergraduate students to accompany me and take part in the study. Although there were some problems with the 2009 data collection, I still obtained useful data and hope to continue data collection in 2010.

\section{$\uparrow$ Literature Cited}

Beever EA, Brussard PF, Berger, J. 2003. Patterns of apparent extirpation among isolated populations of pikas (Ochotona princeps) in the Great Basin. Journal of Mammalogy 84: $37-54$.

Berteaux D, Réale D, McAdam AG, Boutin S. 2004. Keeping pace with fast climate change: can arctic life count on evolution? Integrative and Comparative Biology 44:140-151.
Blumstein DT, Im S, Nicodemus A, \&Zugmeyer C. 2004. Yellow-bellied marmots (Marmota flaviventris) hibernate socially. Journal of Mammalogy 85:25-29.

Brown JH, Valone TJ, Curtin CG. 1997. Reorganization of an arid ecosystem in response to recent climate change. Proceedings of the National Academy of Science 94:9729-9733.

Campbell KL, Hochochka PW. 2000. Thermal biology and metabolism of the American shrew-mole, Neurotrichus gibbsii. Journal of Mammalogy 81:578-585.

Ferández-Salvador R, Gárcia-Perea R, Ventura J. 2005. Effect of climatic fluctuations on body mass of a Mediterranean vole, Microtus cabrerae. Mammalian Biology 70:73-83.

Floyd CH. 2004. Marmot distribution and habitat associations in the Great Basin. Western North American Naturalist 64:471-481.

Gannon WL, Forbes RB. 1995. Tamias senex. Mammalian Species Account No. 502, 6pp.

Gian-Reto W, Beibner S, Burga CA. 2005. Trends in the upward shift of alpine plants. Journal of Vegetation Science 16:541-548.

Hayes JP, O'Connor CS. 1999. Natural selection on thermogenic capacity of high-altitude deer mice. Evolution 53:1280-1287.

Houghton JT, Y Ding Y, Griggs DJ, Noguer M, van der Linden PJ, Dai X, Maskell K, Johnson CA, editors. 2001. Climate Change 2001: The scientific basis. Contribution of Working Group I to the Third Assessment Report of the Intergovernmental Panel on Climate Change. Cambridge University Press, Cambridge.

Humphries MM, Umbanhowar J., McCann KS. 2004. Bioenergetic prediction of climate change impacts on northern mammals. Integrative and Comparative Biology 44:152-162.

Inouye DW, Barr B, Armitage KB, Inouye BD. 2000. Climate change is affecting altitudinal migrants and hibernating species. Proceedings of the National Academy of Science 97:1630-1633. 
Lewis SE. 1993. Effect of climatic variation on reproduction by pallid bats (Antrozous pallidus). Canadian Journal of Zoology 71:1429-1433.

McCarthy JJ, Canziani OF, Leary NA, Dokken DJ, White KS, editors. 2001. Climate change 2001. Impacts, adaptation, and vulnerability. Contribution of Working Group II to the Third Assessment Report of the Intergovernmental Panel on Climate Change. Cambridge (UK) Cambridge University Press.

McNab BK. 2002. The physiological ecology of vertebrates: a view from energetics. Ithaca (NY):Cornell University Press.

Nickerson DM, Facey DE, Grossman GD. 1989. Estimating physiological thresholds with continuous two-phase regression. Physiological Zoology 62:866-887.

Payette S. 1987. Recent porcupine expansion at tree line: a dendroecological analysis. Canadian Journal of Zoology 65:551-557.
Post E. Stenseth NC. 1999. Climatic variability, plant phenology, and northern ungulates. Ecology 80:1322-1339.

Robbins KR. 1986. A method, SAS program, and example for fitting the broken-line to growth data. University of Tennessee Agricultural Experiment Station, Research Report 86-09.

Smith FA, Browning H, Shepherd UL. 1998. The influence of climate change on the body mass of woodrats Neotoma in an arid region of New Mexico. Ecography 21:140-48.

Terblanche JS, Klok CJ, Krafsur ES, Chown SL. 2006. Phenotypic plasticity and geographic variation in thermal tolerance and water loss of the tetse Glossina pallidipes (Diptera: Glossinidae): implications for distribution modeling. The American Journal of Tropical Medicine and Hygiene 74(5):786-794. 